\title{
Growth and Development Strategy of It Software and Service Industry
}

\author{
Rajesh kumar
}

Information Technology (IT), a knowledge-based industry, has the tremendous potential of becoming an engine of accelerated economic growth, productivity improvement for all sectors of the economy and means of efficient governance. It enhances access to information, protects consumers, provides access to government services, makes skill formation and training more effective, improves delivery health services, and promotes transparency. It provides tremendous employment potential and linkages between government and the people both at the rural and urban level. Investment in knowledgebased industries will determine the level of the country's dominant position in the world economy in the next two decades.

Status of IT Software and Service Industry in India: The Indian IT software and service industry has emerged as one of the fastest growing sectors in the Indian economy, with a growth rate exceeding 50 per cent in exports and 40 per cent in the total IT industry over the last five years. Table 1 shows the turnover of this industry including domestic and exports.

Table 1

\begin{tabular}{|c|r|r|r|r|r|}
\hline Year & Domestic & Exports & Total & $\begin{array}{r}\text { Percentage } \\
\text { Growth Rate } \\
\text { (Export) }\end{array}$ & $\begin{array}{r}\text { Percentage Growth } \\
\text { Rate } \\
\text { (Domestic and } \\
\text { Export) }\end{array}$ \\
\hline $1994-95$ & 0.35 & 0.485 & 0.835 & & 46.60 \\
\hline $1995-96$ & 0.49 & 0.734 & 1.224 & 51.34 & 43.40 \\
\hline $1996-97$ & 0.67 & 1.085 & 1.755 & 47.82 & 53.80 \\
\hline $1997-98$ & 0.95 & 1.750 & 2.700 & 61.29 & 44.40 \\
\hline $1998-99$ & 1.25 & 2.650 & 3.900 & 51.43 & 46.10 \\
\hline $1999-2000$ & 1.70 & 4.000 & 5.700 & 50.94 & 44.90 \\
\hline $2000-01$ & 1.96 & 6.300 & 8.260 & 57.50 & \\
\hline
\end{tabular}

\begin{tabular}{lcccc}
\multicolumn{5}{c}{ Table 1: India's GDP and IT Sector } \\
\hline Year & $\begin{array}{c}\text { GDP at current } \\
\text { prices } \\
\text { (in Rs. billion) }\end{array}$ & $\begin{array}{c}\text { IT sector } \\
\text { revenue } \\
\text { (in Rs. billion) }\end{array}$ & $\begin{array}{c}\text { IT sector rev. to } \\
\text { GDP ratio } \\
\text { (in \%age) }\end{array}$ & $\begin{array}{c}\text { IT sector } \\
\text { revenue } \\
\text { (in US \$ billion) }\end{array}$ \\
\hline $1994-95$ & 10128 & 63 & 0.62 & 2.0 \\
$1995-96$ & 11880 & 99 & 0.83 & 2.9 \\
$1996-97$ & 13682 & 137 & 1.00 & 3.8 \\
$1997-98$ & 15224 & 186 & 1.22 & 5.0 \\
$1998-99$ & 17409 & 253 & 1.45 & 6.0 \\
$1999-00$ & 19296 & 362 & 1.88 & 8.2 \\
$2000-01$ & 21043 & 566 & 2.69 & 12.1 \\
$2001-02$ & 22929 & 658 & 2.87 & 13.4 \\
$2002-03$ & 24661 & 780 & 3.16 & 16.1 \\
$2003-04$ & 26954 & 978 & 3.63 & 21.5 \\
$2004-05$ & 29380 & 1276 & 4.34 & 28.2 \\
\hline Source: hitp://maspinic.in and hitp://wwwnasscom.org \\
Note: GDP figures are at market prices.
\end{tabular}

Exports declined during 2001-02, primarily due to the slow-down in the US economy after the 11 September 2001 terrorist attack. However, the NASSCOM-McKinsey Report 2002 has projected that the Indian IT software and service industry will still achieve a turnover of US\$ 80billion (approximately 7.0 per cent of GDP) by 2008, because of the expected increase in the IT Enabled Services (ITES) sector. The IT software and service industry has been categorized into three broad sectors:

- Software Product and Technology Services,

- IT Services, and

- IT Enabled Services.

The projected turnover of industry in India by 2007 and 2008 is given in Table 2. 
Table 2

Projected Turnover of IT Software and Service Industry in India by 2007 and 2008

\begin{tabular}{|c|c|c|}
\hline Category & $\begin{array}{l}\text { By } 2007^{*} \\
\text { (US\$ b) }\end{array}$ & $\begin{array}{l}\text { By } 2008 \\
\text { (US\$ b) }\end{array}$ \\
\hline $\begin{array}{l}\text { A. Exports } \\
\text { Software Product and Technology } \\
\text { Services } \\
\text { IT Services } \\
\text { IT Enabled Services }\end{array}$ & $\begin{array}{r}8 \\
22 \\
18\end{array}$ & $\begin{array}{l}11 \\
30 \\
24\end{array}$ \\
\hline Total & 48 & 65 \\
\hline B. Domestic & 12 & 15 \\
\hline$(A+B)$ & 60 & 80 \\
\hline
\end{tabular}

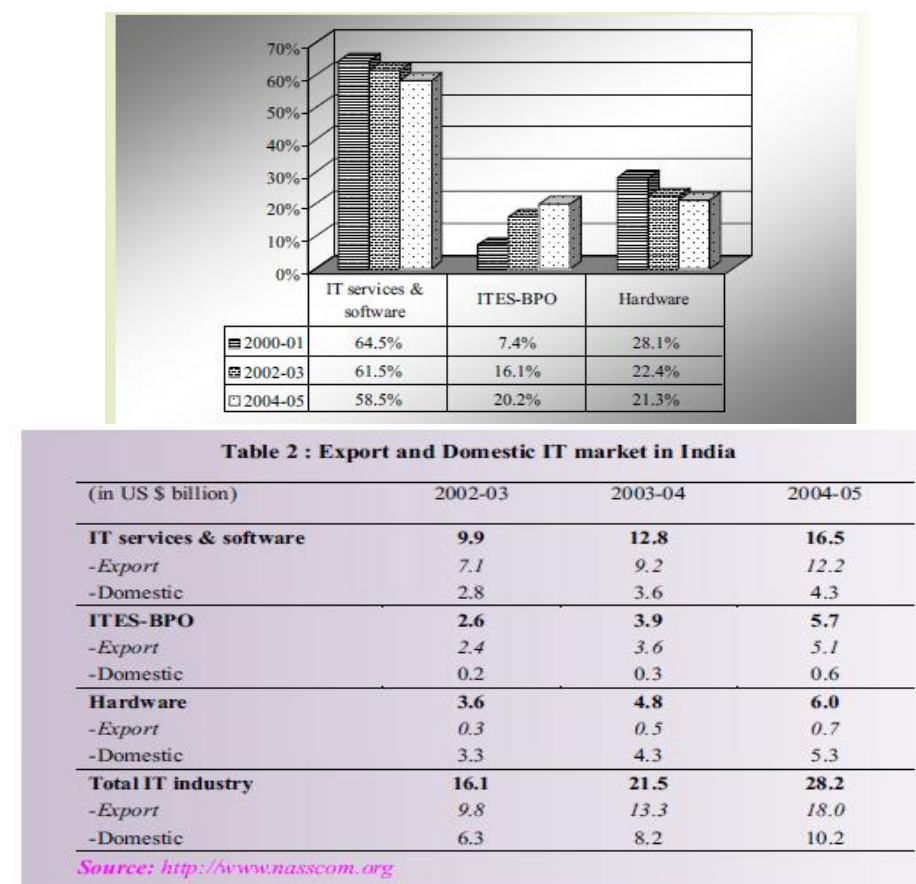

Status of IT Software and Service Industry in Punjab: During the eighth plan period, i.e., 1992-1997, there was hardly any activity in the IT software and service industry in Punjab. It made a beginning only when the Software Technology Park (STPI) of the Government of India came into operation at Mohali in 1998-99. Since the announcement of the policy of tax holiday for STPIs by the Government of India for a period of 10 years, 145 software units have registered with STPI Mohali till 2001-02. However, the number of units in operation is only 65. Table 3 shows the state-wise software exports of India through STPI during 2000-01.

Figure 2 : Growth of IT professionals in India

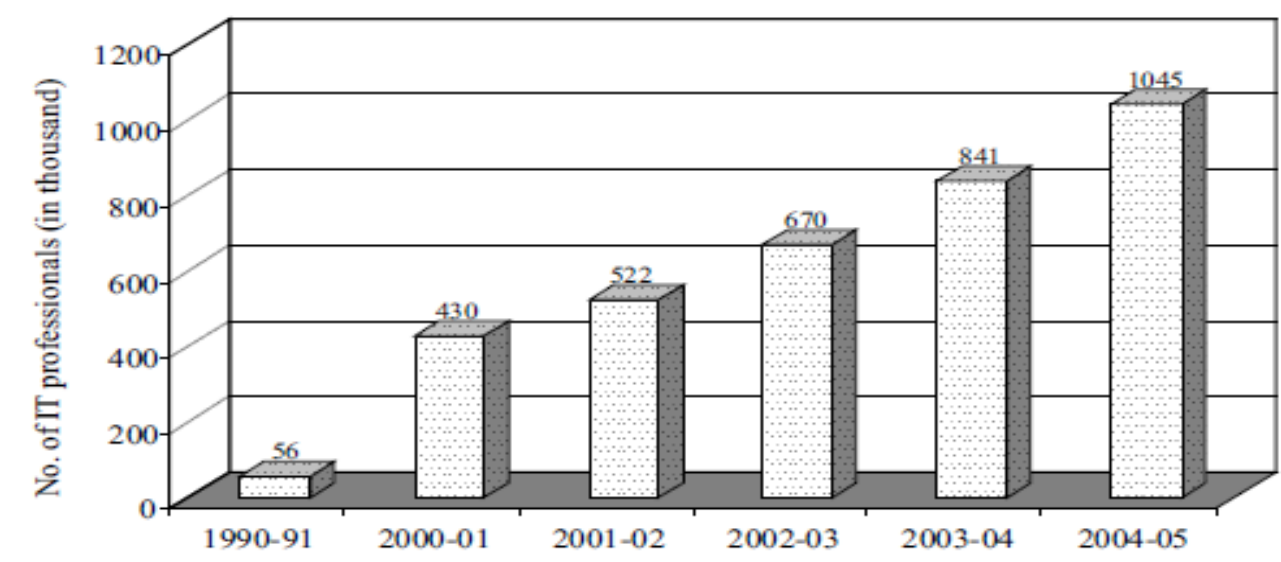


Table 3

State-wise Software Exports through STPI* of India during 2000-01
\begin{tabular}{|l|r|r|}
\hline \multicolumn{1}{|c|}{ State } & Exports (in crore) & Percentage \\
\hline Karnataka & 7475 & 37.27 \\
\hline Tamil Nadu & 2956 & 14.74 \\
\hline Maharashtra & 2570 & 12.82 \\
\hline Andhra Pradesh & 2017 & 10.06 \\
\hline Uttar Pradesh & 1660 & 8.23 \\
\hline Haryana & 1450 & 7.23 \\
\hline Delhi & 1100 & 5.49 \\
\hline West Bengal & 250 & 1.25 \\
\hline Orissa & 200 & 1.00 \\
\hline Kerala & 141 & 0.70 \\
\hline Gujarat & 102 & 0.51 \\
\hline Punjab (STPI, Mohali) & $\mathbf{5 2}$ & $\mathbf{0 . 2 6}$ \\
\hline Madhya Pradesh & 50 & 0.25 \\
\hline Rajasthan & 30 & 0.15 \\
\hline Total & 20054 & 100.00 \\
\hline
\end{tabular} Source: Software Technology Parks of India
Note:

Table 4 shows IT software and service exports through STPI, Mohali (Punjab) from 1998-99 to 2001-02. In 2001-2002, the exports were Rs. 70 crore.

Table 4

IT Software and Service Exports through STPI, Mohali

\begin{tabular}{|l|r|r|r|r|}
\hline & $1998-99$ & $1999-00$ & $2000-01$ & 2001-02 \\
\hline IT Enabled Services & 4.70 & 7.01 & 17.36 & 30.00 \\
\hline Software Development & 3.07 & 7.79 & 34.64 & 40.00 \\
\hline Total & 7.77 & 14.80 & 52.00 & 70.00 \\
\hline
\end{tabular}

During the last two years, the private sector has been in the process of setting up IT infrastructure in Punjab: Mahindra \& Mahindra software technology park in Mohali; Reliance, HFCL and VSNL are setting up telecom infrastructure in Punjab. The progress is rather very slow. The share of Punjab in the Indian IT software and service industry is very meagre, i.e., 0.26 per cent in 2001-2002. (See Table 3) During the Ninth Plan, there has not been any significant progress in the IT industry, in spite of the fact that the policies of the Punjab Government are as attractive as of such other states as Karnataka. Some of the specific constraints for the insignificant growth of IT Industry are as follows:

- Quality of infrastructure required for IT industry was not available.

- Quality of human resource was not matching with IT industry's requirements.

- Insufficient funds for IT industry.

- Lack of direction and vision.

- Non-conducive environment.

The IT industry in other states of India, where high quality infrastructure and trained manpower are available, has achieved accelerated growth and increased its share from 0.6 per cent to six per cent of the total turnover of the IT industry in India during the last five years, mainly due to robust growth in the ITES segment. The IT Industry in Haryana has grown from a turnover of Rs. 400 crore in 1999-2000 to Rs. 2,054 crore in 2000-01, an almost five fold increase. Punjab, therefore, can also aim at and achieve five per cent share of the total IT industry in India by the year 2007, with emphasis on ITES. In view of the present status of the software industry in Punjab, i.e., 0.26 per cent share, the projection of five per cent share by 2007 is very optimistic. To achieve this, a fast track approach will have to be adopted. The suggestions and recommendations made in this report have to be implemented to ensure such rapid growth. A conducive environment must be created to ensure that both national and international MNCs set up IT industries in Punjab.

For achieving a five per cent share, it is recommended that targets be fixed for a four per cent share of the national turnover (according to the NASSCOM-McKinney, Report 2002) for software products and technology services and the same for IT services, because each of these involves high technology and longer gestation period, and a seven per cent share for IT Enabled Services, as it has a shorter gestation period and a huge employment potential. Projected category-wise turnover of IT software and service industry in Punjab by 2007 is shown in Table 5. 
Table 5

Projected Category-wise Turnover of IT Software and Service Industry in Punjab by $2007^{*}$

\begin{tabular}{|c|c|c|}
\hline Software and Service Industry & $\begin{array}{l}\text { Targeted percentage } \\
\text { share for Punjab in } \\
\text { terms of projected } \\
\text { national turnover }\end{array}$ & $\begin{array}{l}\text { Turnover in 2006- } \\
07 \text { Rs. in Crore (In } \\
\text { US\$ b) }\end{array}$ \\
\hline $\begin{array}{l}\text { A. Exports } \\
\text { "Category A" } \\
\text { Software Product and Technology Services } \\
\text { "Category B" } \\
\text { IT Services } \\
\text { "Category C" } \\
\text { IT Enabled Services } \\
\text { Total }\end{array}$ & $\begin{array}{l}4 \\
7\end{array}$ & $\begin{array}{r}1600(0.32) \\
4400(0.88) \\
6300(1.26) \\
12300(2.46) \\
\end{array}$ \\
\hline B. Domestic & 5 & $3000(0.60)$ \\
\hline$(A+B)$ & 5 & $15300(3.06)$ \\
\hline
\end{tabular}

Software Product and Technology Services provide a high growth opportunity for the Indian software industry. Indian companies have a market potential of software product development, such as enterprise software (e-business solution, ERP, e-corporate governance), consumer software (personal productivity tools) and embedded software. Indian companies have developed a number of highly acclaimed and popular packages, such as HR management and business accounting by TCS, banking automation packages by Infosys, ERP tools by RANCO, etc. This segment is high-technology oriented and requires highly skilled professionals. In the shorter term, there will be limited development in the area, as R\&D budgets of the companies are limited. Taking these factors into account, Punjab has to aim to achieve at least four per cent of US\$ 8billion, i.e., US\$ 0.32 billion (Rs. 1,600 crore) by 2007 (Table 5).

IT Services are undergoing a structural change from client/server to web/packagebased services. This will form the major chunk of IT services. Growth in IT services will continue to provide the biggest opportunity, while other sectors of IT software industry will also make a significant contribution. IT services, both export and domestic, will grow rapidly as new opportunities are emerging in management/consulting services, application maintenance and Internet services. The major users of IT services are the government, financial services and banking, manufacturing and retail and distribution.

New areas likely to emerge are communication, healthcare and utilities, as these will increasingly be deregulated. However, IT services essentially require high-quality manpower, state of the art skills, world-class telecom and IT-knowledge based environment. The importance of IT services can be judged from the fact that they will account for 45.8 per cent of the total turnover of the software industry, i.e., US\$22billion out of US\$ 48billion projected export by 2007. Punjab should aim at achieving at least four per cent of US $\$ 22$ billion, i.e., US\$ 0.88 billion (Rs. 4,400 crore) by 2007 (Table 5)

The ITES sector in India has emerged as a key engine of growth for the Indian IT industry and the technologyled services industry. This sector has grown from Rs. 2,400 crore in 1999-2000 to Rs. 4,100 crore in 2000-2001, providing employment to 70,000 people. It covers a wide range of services, some of which are:

- Customer-interaction services including call centres.

- Back offices, revenue accounting, data entry, data conversion and HR services.

- Transcription and translation services.

- Content development and animation.

- Other services, including remote education, data search, GIS, market research and network consultancy.

The employment potential in ITES is substantial and the gestation period is lesser than in other sectors of the IT industry. It is highly quality-oriented, human -resource intensive and requires consistent performance with high standards. Therefore, the success of ITES will mainly depend on the quality of manpower and infrastructure. Knowledge-based skill-oriented training is the key to quality of manpower. ITES to succeed requires top-class infrastructure with adequate bandwidth, fault-free and continuous power with two layers of redundancy to avoid any breakdown. US technology firms are rapidly shifting back-office functions to India. Foreign firms are eagerly waiting to set up centers to process financial claims, payroll-data, building customer-support desk, etc. According to a NASSCOM study, GE Capital has saved US\$270million, CITI Bank US\$70million and British Airways (BA) US\$42million, a total

of US\$ 385million saved per year, as a result of their shifting back-office operations from US to India. Most of the firms already in India are in the process of expanding and eager to set up operations in other areas of the country. ITES, or remote processing, presents a golden opportunity for Punjab. For this, the state has to emphasize on skill-formation through world-class training and infrastructure building. Punjab needs to garner at least seven per cent share of the total revenue of India in ITES. This can provide employment to 77,000 educated youth and generate a turnover of US\$1.26billion (Rs. 6,300 crore) by 2007 (Table 5). 
A high-level committee of experts should be constituted for the promotion of the IT industry in the state to formulate a policy for ensuring a hassle-free and conducive environment to attract MNCs and NRIs to set up IT industries in Punjab. Special emphasis has to be placed on NRIs, keeping in view that a large number of them from Punjab are actively involved in the IT industry in USA and other developed countries. The proposed committee of experts should also monitor the growth of the IT industry in the state.

IT HUMAN RESOURCE DEVELOPMENT: India's main competitive advantage in the software and services industry is its abundant English-speaking and cost-effective human resource. As on 31 March 2001, it has 3,40,000 people working in the software and service sector in India, the second largest IT workforce after the US. According to the projections of the Ministry of Information Technology (MIT) Report, India needs to develop more than 22 lakh high quality knowledge workers in software and related areas by 2008. To achieve an overall target of five per cent of the national turnover, i.e., US\$ 3.06billion by 2007 (Table 5), Punjab would need 99,000 IT-trained manpower which has to be high quality and of the right mix of technical, business and functional skills to meet the needs of all business segments.

According to the MIT Report, human resource in IT has been categorized into three categories: Category 'A' includes higher-end professionals, category ' $\mathrm{B}$ ' comprises professionals mainly for IT services and category ' $\mathrm{C}$ ' for ITES. To achieve the projected turnover, Punjab needs 6,000 professionals for category ' $A$ '. 16,000 for category ' $\mathrm{B}$ ' and 77,000 for category ' $\mathrm{C}$ '. Table 6 shows the projected category-wise IT manpower requirements by 2007 in Punjab (Table 6). It is necessary to formulate appropriate strategy and measures in respect of requisite infrastructure with special focus on human resource, taking into account emerging educational technologies, to achieve the projected turnover of the Punjab IT industry. The total estimated cost of manpowerquality improvement is Rs. 60 crore during 2002-07. (Rs. 30 crore for Category 'C' and Rs. 15 crore each for Category ' $A$ ' and Category ' $B$ ')

Table 6

\begin{tabular}{|c|c|c|c|}
\hline & Qualification & $\begin{array}{r}\text { Estimated IT } \\
\text { Manpower } \\
\text { Requirements } \\
\text { (India) }\end{array}$ & $\begin{array}{r}\text { Projected IT } \\
\text { Manpower } \\
\text { Requirements as } \\
\text { percentage of the } \\
\text { National } \\
\text { Requirement } \\
\end{array}$ \\
\hline $\begin{array}{l}\text { Category 'A' } \\
\text { Software } \\
\text { Product and } \\
\text { Technology } \\
\text { Services } \\
\end{array}$ & $\begin{array}{l}\text { MS/M.Tech/B.Tech in Computer } \\
\text { Science }\end{array}$ & $1,50,000$ & $6,000(4 \%)$ \\
\hline $\begin{array}{l}\text { Category 'B' } \\
\text { IT Services }\end{array}$ & $\begin{array}{l}\text { B.Tech in Non-Computer } \\
\text { Science, MCA }\end{array}$ & $4,00,000$ & $16000 \quad(4 \%)$ \\
\hline $\begin{array}{l}\text { Category 'C' } \\
\text { IT Enabled } \\
\text { Services }\end{array}$ & $\begin{array}{l}\text { BA/B.Sc/B.Com \& Diploma and it } \\
\text { is }\end{array}$ & $11,00,000$ & $77,000(7 \%)$ \\
\hline All & & $16,50,000$ & $99,000(6 \%)$ \\
\hline Sour & \multicolumn{3}{|c|}{$\begin{array}{l}\text { Projections based on Ministry of Information Technology, Report for Tenth Plan } \\
(2002-2007) \text {, Government of India. Figures have been proportionately adjusted } \\
\text { as per the revised projections by NASSCOM-Mckinsey Report, 2002, from the } \\
\text { earlier NASSCOM-Mckinsey Report, } 1999 \text {. }\end{array}$} \\
\hline
\end{tabular}

\section{Recommendations for IT HRD}

- For quality improvement, Punjab has to train 99,000 high-quality manpower during 2002-2007. IT services $(16,000)$, IT software product and technology services $(6,000)$ and ITES $(77,000)$.

- Upgradation, including networking, of infrastructure of the engineering colleges.

- Training of faculty to meet the required standards. Interaction and exchange of faculty members with institutes of higher learning in India and abroad.

- An IIT of an international standard should be set up to move up the value chain in IT industry. It will help the state catch up with other IT-developed states in India. It will also help to fill the much-needed gap in the availability of quality human resource.

- To ensure that high-quality IT manpower is being produced by both government and private institutions, it is recommended that Punjab Government should set up a State Council for Computer and IT Education (SCCE), a body of experts responsible for monitoring and fixing minimum standards for the quality of IT education in the state.

IT INFRASTRUCTURE: In today's IT-savvy world, the growth of every economy is linked with the growth of Information Technology and, in turn, sound and quality infrastructure is absolutely essential for this. During last decade, the main contribution towards building IT infrastructure has been the Software Technology Park at Mohali, where private sector companies are in the process of setting up telecommunication infrastructure. So far the performance of Punjab has been dismal as compared to other IT-developed regions in India. During 2000- 
2001, out of the total export of Rs. 20,052 crore from STPIs across the country, Punjab had a total export of Rs. 52 crore, while Bangalore Software Technology Park had an export of Rs. 7,475 crore, Noida Rs. 4,350 crore, Chennai Rs. 2,956 crore, Mumbai Rs. 1,610 crore and Pune Rs. 960 crore. It is vital to develop the quality IT infrastructure required to achieve the projected turnover of US\$3.06billion by 2007 (Table 4) and to meet the other infrastructure requirements for IT-usage in various applications, including e-governance. The main constituents of IT infrastructure are telecommunication-backbone both national and international, V-SAT infrastructure and Internet Service Providers (ISPs).

IT software and services including ITES and Internet are among the major users of the IT infrastructure with adequate communication bandwidth. This sector is very sensitive to the quality as well as the size of the infrastructure. Presently, the infrastructure that exists in the telecommunication sector in Punjab along with the implementations of the future plans of the VSNL and other private operators such as HFCL and Reliance, is likely to meet the basic requirement of IT infrastructure in terms of good-quality connectivity by 2007 . IT infrastructure being vital for the development of the IT Industry, the Ministry of Information Technology (MIT), Government of India in their Tenth Plan

has recommended special norms for bandwidth. The Punjab Government has to ensure

its timely and speedy implementation.

According to the study by NASSCOM, by 2002, the requirement of international bandwidth for connectivity to Internet was projected to be $100 \mathrm{GbPs}$. However, these projections could not be achieved as the expected growth of Internet could not take place, due to very high telephone tariff along with equally high cost of Internet backbone. This has resulted in inadequate demand. The number of Internet users and the availability of bandwidth are linked with each other; as such the bandwidth requirement is market dependent. However, recently the basic service providers have reduced telephone charges, but the numbers of Internet users/Internet subscribers are not increasing at the expected rate.

The Punjab Government has to formulate a policy to ensure usage of Internet in all its departments, public places, down to block and village level. It has to ensure adequate demand by way of creating a suitable IT culture and suitable infrastructure, so as to improve the viability of the ISPs. It is proposed to develop three new IT cities and upgrade the existing infrastructure at Mohali, to achieve the projected turnover of the IT software industry. The infrastructure and quality should be such that each IT city should be able to generate, on an average, a turnover of between Rs. 3,000-5,000 crore yearly by 2007. The proposed IT cities should have, besides good quality telecom infrastructure, adequate basic infrastructure in terms of continuous uninterrupted power supply, good quality roads, efficient transport, proximity to airport, a good education and an R\&D centre. The selection of these IT cities has to be based on the academic environment. Keeping this in view, the proposed new cities are Patiala, Jalandhar and Ludhiana.

They have the academic environment suitable for the growth of the IT industry as already in place. However, these can be easily upgraded further so as to become 'Centres of Attraction' for investors to set up their production/research and development facilities in the field of information technology. The estimated cost of each IT city may be of the order of Rs. 150-200 crore and the cost of upgradation of the infrastructure at Mohali will be another Rs. 50 crore. Detailed proposals for each IT city have to be drawn up separately. Each city will have an STP as a prime mover. It is proposed that each IT city should have a separate development authority on the pattern of the Noida Development Authority, and function independently, to ensure its proper growth and development.

Venture Capital (VC) has played a vital role in the materialization and commercialization of innovative and creative ideas. The Indian software and service industry has emerged as one of the fastest growing sectors in the country. A large number of software companies, started by research-minded professionals with innovative ideas, have benefited and have succeeded in their ventures, with the help of the initial funding through seed money and venture capital. USA is a prime source of venture capital. According to the Indian Venture Capital Association (IVCA), venture capital funding in India was US\$ one billion in the year ending March 2002 and is likely to go up by 50 per cent to US\$1.5billion in the current financial year.

The state government has already taken the initiative in this regard by setting up a Rs. 20 crore venture fund for the growth of the software industry in the state. It is suggested that fund be increased to Rs. 50 crore and a special allocation of Rs. 30 crore be made for the IT industry in the state. However, the state has to play a more proactive and pragmatic role by providing funds to bright young talented entrepreneurs, so that startups and ventures by qualified professionals are not unsuccessful for want of initial financial assistance. This will go a long way in building confidence among the prospective young entrepreneurs and will create a much needed conducive and enabling culture, important for the growth of the IT software and service industry in the state.

E-GOVERNANCE: The objectives of e-governance are information dissemination to the public with any where or any time services to citizens, making the government machinery more easily accessible, transparent, effective, efficient, and accountable. A comprehensive citizen-service portal should be set up for this purpose, 
with such services as issuance of general certificates; services related to taxes, revenue, transport, permits and licenses, registration of all types; pension schemes, social security and welfare schemes; education training; employment; housing; infrastructure; financial assistance schemes; industries; agriculture; and other miscellaneous services. This will not only help implement e-governance but will also inculcate and create an IT culture in the state. Implementation of e-governance necessitates top priority to computerization and networking of different departments at the headquarter, district and block level; identification of key departmental applications; creation of data-bases, digitization of public domain information; and availability of departmental data on a day-to-day basis.

The state government has already taken up an ambitious e-governance project, called e- Governance-Citizen Interface, to implement e-governance. It has chosen Fatehgarh Sahib as a pilot district for the implementation of this project. It envisages extension of the communication network, including hardware and software, within the district to connect the different offices linked with the DC office, which further will be connected to district centres and state headquarters. The state should ensure the completion of the project in Fatehgarh Sahib and set up similar projects in other districts so that government and the people draw maximum benefit from IT and egovernance. To facilitate and implement e-governance in the state, the following measures are recommended:

Launch a massive program for rural and urban connectivity. Establish Punjab-wide Area Network (PUNWAN) to provide connectivity between state headquarters, Secretarial Area Network, Department Local Area Network, districts, sub-divisions, blocks and villages

- Facilitate estimated 2.5 million Internet connections by 2007, in line with the policy of the Government of India

- Facilitate IT kiosks within the cycling distance of four to five kms, including rural areas, by 2005, through private sector participation. Government of Punjab should progressively make available access to Internet connectivity and e-mail facility in all government offices.

- Launch a program for training panches and sarpanches at the village level and mayors and deputy mayors at the municipal corporation level.

According to the recommendations of the Working Group on IT for Masses, set up by the Government of India, five per cent of the state's total budget should be allocated for IT induction. Punjab has already set up Department of Information Technology (DoIT). It is proposed that it should be further strengthened in terms of expertise and funds. It is recommended that at least 0.5 per cent of the budget in the first year, progressively increasing it to two per cent in the terminal year of the plan period, should be utilized for promoting and implementing e-governance. It is strongly recommended that e-governance of the state should be implemented in a holistic and integrated manner through a monitoring cell, with defined rules and procedures based on principles of equity, responsibility, transparency and accountability.

It should be able to monitor the performance and the status of all the projects, departments and ministries against the set targets. In case of non-performance, the monitoring cell will receive an alert signal and the cause.

IT FOR MASSES: The rural population in Punjab constitutes 65 per cent of the State's population. Being predominantly an agricultural state, the quality of life and the health of the its economy is largely driven by the performance of the rural sector. Information technology provides new opportunities to tackle problems related to rural poverty, health, illiteracy, unemployment and environmental degradation. The special IT Task Force, constituted by the Government of India, has recommended the use of state-of-the-art information technology for the development of agriculture and rural development, on the lines of the successful Warana project in the Kolhapur and Sangli districts of Maharashtra. This project effectively demonstrates the contribution of an IT infrastructure to the accelerated socio-economic development of a cluster of 70 contiguous 'Wired Villages'.

The project aims to utilize IT to increase the efficiency/productivity of the existing cooperative enterprise, by setting up a state-of-the-art computer communication network and create a data-base of villages on different socio-economic aspects such as health, education, water supply, sanitation and population. It also provides information on agricultural-related schemes, employment generation schemes, and government procedures for getting ration cards, birth and death certificates, etc., to the villagers. It is proposed that Punjab should adopt the "Wired Village" concept to network its 12,400 villages with all information and communication facilities, including Internet. To cover the entire state, a total of 138 'Community Information Dissemination Centres' (CIDCs), one each at the block level, should be set up, which will be linked to every village. These centres will also effectively disseminate information related to the 29 subjects transferred to the Panchayats under the 73rd Amendment to the Constitution.

CIDCs also function as IT kiosks and will provide direct linkages between the masses and the government. CIDCs will further organize training of panches and sarpanches in the use of IT and its benefits for their day-today requirements. The total investment for setting up such 138 Centres has been worked out to be Rs. 372 crore, at the rate of Rs. 2.7 crore per CIDC. (On an average rupees three lakh per village and one CIDC will cover 90 villages). It is recommended that the Punjab makes efforts to get the project funded by the Government of India. 
(Government of India has already funded a similar project in the Northeast region of the country at a cost of Rs. 220 crore covering 487 centres). The programme is on a revenue-sharing basis and is to be so formulated that, after an initial gestation period of two to three years, CIDCs will be selfsustaining. It would also provide employment to approximately 25,000 educated youth in the rural areas of Punjab during 2002-2007. The Government of India has already made provision for requisite investment covering 6,000 CICs (CIDCs) to be set up all over the country, as reported in MIT Report on Tenth Five Year Plan.

CIDCs will also help in improving productivity and performance of agriculture. Support and services of various stakeholders and extension agencies, such as Punjab Agriculture University, Ludhiana, State Agriculture Department, Mandi Board, Markfed, Sugarfed, etc., and other agriculture-related industries should also be taken up for updating the latest information on products and services, new technologies and practices. IT can be used in all aspects of agriculture. It can play a major role in crop management, enhancing productivity and crop yields through information on farm practices, seeds, other inputs of production, weather information, enhancing realization, cutting down intermediaries, better pre- and post- harvest management, water utilization and management, pest and disease control, etc. The Land Information System can provide information about markets, food-pricing, imports and exports, tariffs and quotas, underproduction and over production, and physical information about soils, hydrogeology and rainfall, etc. IT applications can be effectively used for management and monitoring of environment resources, pollution warning systems, environmental emergency management systems for floods, forest fires and other natural disasters. IT can also be suitably employed in small and tiny industries for online and real-time information to help small and marginal artisans in their sales and marketing efforts. This will not only help them earn better and boost their morale, but preserve these rare skills, which otherwise are on the verge of extinction.

The Government of India has proposed the setting up of a network called, Vidya Vahini, to carry the benefit of IT to the students, Today, in India, there are more than nine lakh schools catering to the needs of more than 25 crore students and one crore teachers. Most of these schools have no access to the information age. Under the Vidya Vahini programme, schools and higher learning institutes are proposed to be connected with an integrated voice, data and video network. The Government of India has proposed to introduce this programme in two phases. In the first phase, i.e., in the first two years of the plan, 60,000 schools are proposed to be connected to the network. Punjab should get 5,000 schools networked in the first phase and 5,000 more in the second phase. It is estimated that rupees two lakh will be required for each school, to implement the recommendation of Government of India, It is also recommended that all these schools should only be from rural areas. Timely and speedy implementation of the project by the state will go a long way in furthering the use of IT for the masses.

RESEARCH, DESIGN AND DEVELOPMENT (RD\&D): Nations investing in human resource development, research \& development and high quality university education have achieved worldwide leadership and scholarship. Today, the Quality-of-Life index in those nations is unparallel as compared to other developing nations. In the liberalized, globalized environment, under the WTO regime, it has become imperative to develop technologies, newer products and services of international quality, to remain competitive. Research and development is the way to meet this challenge. In the field of IT in India, most of the research and development projects have so far been sponsored and funded by the Government of India. However, Karnataka, Andhra Pradesh and Maharashtra have undertaken a few design and development projects sponsored and funded by the respective governments. RD\&D is vital for the growth and development of the IT industry, for Punjab to become a leading IT destination and move up the value chain, Design and development projects with commercial potential should be identified and the participation of the private sector in them encouraged.

The state must focus on short-term as well as long-term RD\&D projects. Short-term projects with direct applications in industry, involving less risk and a short gestation period, should be taken up on a priority basis. Other important areas include development of software for the computerization of different government departments and application software for rural masses in the local language. In the longer term, the state must focus on key emerging technologies, such as wireless technology, second generation Internet, software level integration, and motivate MNCs to set up their RD\&D centres in Punjab and financial and technical participation of international agencies to leverage their worldwide experience. The concept of subcontracted research with system-integration should be encouraged to help in developing system-integration expertise and design of products. An exclusive R\&D fund has to be set up to formulate and implement these RD\&D programmes, Rs. 20 crore may be allocated during 2002-07. In addition, technical and financial support and participation by the Government of India, international agencies, MNCs and private sector are important. 


\begin{tabular}{|c|c|c|c|c|}
\hline Area & $\begin{array}{l}\text { Estimated total } \\
\text { Investment }\end{array}$ & $\begin{array}{l}\text { To be } \\
\text { funded by } \\
\text { Punjab Govt }\end{array}$ & $\begin{array}{l}\text { To be } \\
\text { funded by } \\
\text { GOI }\end{array}$ & $\begin{array}{l}\text { To be } \\
\text { funded by } \\
\text { Private } \\
\text { sector }\end{array}$ \\
\hline $\begin{array}{l}\text { Human Resource Development } \\
\text { a) HRD Quality improvement } \\
\text { b) Setting up an IIT }\end{array}$ & $\begin{array}{r}60.00 \\
150.00\end{array}$ & $\begin{array}{l}45.00 \\
-\end{array}$ & 150.00 & $\begin{array}{l}15.00 \\
-\end{array}$ \\
\hline $\begin{array}{l}\text { IT Infrastructure } \\
\text { a) Setting three IT cities at Patiala } \\
\text { (Rs. } 175 \text { crore), Jalandhar } \\
\text { (175 crore and Ludhiana (Rs. } \\
175 \text { crore and upgrading } \\
\text { Mohali (Rs. } 50 \text { crore) } \\
\text { b) Venture Capital } \\
\text { Additional fund for IT }\end{array}$ & 575.00 & 115.00 & - & 460.00 \\
\hline $\begin{array}{l}\text { E-Governance } \\
0.5 \text { per cent in the first year to } 2.0 \\
\text { per cent in the last year of the plan }\end{array}$ & 188.6 & 188.6 & - & - \\
\hline $\begin{array}{l}\text { IT for Masses } \\
\text { Setting } 138 \text { wired CIDCs at block } \\
\text { level }\end{array}$ & 372.00 & & 186.00 & 186.00 \\
\hline $\begin{array}{l}\text { Vidya Vahini Programme (GOI) for } \\
10000 \text { Schools }\end{array}$ & 200.00 & & 200.00 & - \\
\hline Research Design \& Development & 20.00 & 20.00 & - & - \\
\hline Total & 1595.60 & 398.60 & 536.00 & 661.00 \\
\hline
\end{tabular}

Information Technology-A Growth Navigator for Small Scale Industries in India: Small scale industries (SSI) have a significant role in the Indian economy in view of its contribution to production, employment, and export. However, since 1991 small scale industries in India find themselves in an intensely competitive environment due to globalization, domestic economic liberalization, and dilution of sector specific protective measures. The formation of World Trade Organization in 1995 also forced the member countries (including India) to drastically scale down the restrictions on import. This article analyzes the various factors influencing the growth of small scale industries in India. Information Technology (IT) is one of the significant factors, which is, in general, not used by the small scale industries in India for their production and business process, in the growth of small scale industries in India. Further on the basis of Nolan's 'Stages of growth model' the stages of use of information technology in small scale industries are studied.

The development of small scale industries (SSI) has been one of the major planks of India's economic development (Bala Subrahmanyam, 2005). Small scale industries have a significant role in Indian economy in view of its contribution to production, employment and export. In 2003 and 2004, there were 11.39 million small scale industries in India contributing 39.42\% in total industrial production and 6.71 percent in gross domestic product (GDP) (Ministry of SSI, 2004-05). Small scale industries provide employment to about 27.14 million persons and contribute 35 percent of the total export form India (Ministry of SSI, 2004-05). However, since 1991 small scale industries in India find themselves in an intensely competitive environment due to globalization, domestic economic liberalization and dilution of sector specific protective measures (Bala Subrahmanyam, 2005). The formation of World Trade Organization in 1995 also forced the member countries (including India) to drastically scale down the restrictions on import. Due to the increased competitive force in the globalize market place it is important for a small business to know their customers, have open lines of communication, provide quality service and offer competitive price to maintain market share (Lee \& Maniam, 2007). Small scale industries play a vital role in the economic development of India, however the performances of such enterprise have declined in recent years. Through a study of literature it is observed that information technology is a significant factor which influences the growth of small scale industries. Information Technology can be used to create competitive opportunities for the organizations (Beheshti, 2004).

Role of Small Scale Industries in the Growth of Indian Economy: The growth of industries in small-scale sector has been striking feature in the economic development of India. It has contributed to the overall growth of the country. Today SSI sectors occupy a place of strategic importance in Indian economic structure due to its considerable contribution in terms of output, export and employment (Bala Subrahmanyam, 2005). In 2003 to 2004 the growth rate of small scale industries were 8.6 percent and the growth rate of overall industrial sector was 6.9 percent (Ministry of SSI, 2004-05). SSI has higher growth rate of production as compared to the overall growth rate of industrial sector (Table 1). Small scale industries have significant contribution to the total industrial production and GDP (Table 1). In the year 2003-04 the contribution of small scale industries in total industrial production was 39.42 percent and

the contribution in GDP is 6.71 percent (Ministry of SSI, 2004-05). Thus small scale industries play a significant role in the economic growth of India. 
Table 1. Contribution of SSI to Indian economy

\begin{tabular}{|c|c|c|c|c|}
\hline Year & $\begin{array}{c}\text { Growth rate of } \\
\text { SSI sector (\%) }\end{array}$ & $\begin{array}{c}\text { Growth rate of rate } \\
\text { of overall industrial } \\
\text { sector (\%) }\end{array}$ & $\begin{array}{c}\text { Contribution of SSI } \\
\text { in Total Industrial } \\
\text { Production (\%) }\end{array}$ & $\begin{array}{c}\text { Contribution of SSI } \\
\text { in Gross Domestic } \\
\text { Product } \\
\text { (GDP) (\%) }\end{array}$ \\
\hline $1997-1998$ & 9.2 & 6.7 & 39.70 & 7.02 \\
\hline $1998-1999$ & 7.8 & 4.1 & 39.94 & 6.81 \\
\hline $1999-2000$ & 7.1 & 6.7 & 40.02 & 6.69 \\
\hline $2000-2001$ & 8.0 & 5.0 & 39.91 & 6.86 \\
\hline $2001-2002$ & 6.1 & 2.7 & 39.63 & 6.67 \\
\hline $2002-2003$ & 7.7 & 5.7 & 39.48 & 6.82 \\
\hline $2003-2004$ & 8.6 & 6.9 & 39.42 & 6.71 \\
\hline
\end{tabular}

(Source: Ministry of SSI, , 2004-05)

Table 2. Growth of Indian small scale industries: $1990 \mathrm{vs.1980 \textrm {s }}$

\begin{tabular}{|l|c|c|c|c|}
\hline \multicolumn{1}{|c|}{ Periods } & Units* & Employment $^{*}$ & Output* $^{*}$ & Exports* $^{*}$ \\
\hline 1980 s & 8.40 & 5.84 & 18.66 & 19.38 \\
\hline 1990 s & 5.62 & 4.00 & 15.31 & 20.62 \\
\hline $1980-81$ to $1985-86$ & 9.18 & 6.21 & 16.88 & 11.00 \\
\hline $1985-86$ to $1990-91$ & 7.63 & 5.47 & 20.46 & 28.40 \\
\hline $1990-91$ to $1995-96$ & 6.88 & 4.02 & 18.05 & 30.42 \\
\hline $1995-96$ to $2000-2001$ & 4.37 & 3.99 & 12.62 & 11.56 \\
\hline
\end{tabular}

Note: *Figures represents the Compound Average Growth Rate (CARG) (\%) (Source: Bala Subrahmanyam, 2005)

The Information Technology Industry is the fastest growing segment of the Indian economy. The Information Technology Sector has grown in size from Rs. 5,450 crores in 1994-95 to about Rs. 64,200 crores in 2001-02 contributing $0.59 \%$ and $2.87 \%$ to G.D.P. growth respectively in the corresponding periods (Source: IDC, NASSCOM, 2002). The composition of Hardware and Software exports is estimated as follows:

\begin{tabular}{|l|c|c|}
\hline \multicolumn{1}{|c|}{ Description } & $\begin{array}{c}1994-95 \\
\text { Rs. } 5450 \text { crore }\end{array}$ & $\begin{array}{c}2001-02 \\
\text { Rs. } 64200 \text { crore }\end{array}$ \\
\hline Software and Service Exports & $28.3 \%$ & $57.4 \%$ \\
\hline Domestic Software and Services & $17.9 \%$ & $17.3 \%$ \\
\hline Hardware peripherals and networking & $48.4 \%$ & $22.3 \%$ \\
\hline Training & $5.5 \%$ & $2.9 \%$ \\
\hline
\end{tabular}

The countrywise Indian Software Exports in 2000-01 was as follows:

\begin{tabular}{|l|r|r|}
\hline Country & Rs. in crores & Percentage \\
\hline USA & 17336 & 61.15 \\
\hline UK & 3355 & 11.84 \\
\hline Japan & 1021 & 3.60 \\
\hline Germany & 900 & 3.20 \\
\hline Singapore & 540 & 1.90 \\
\hline Canada & 425 & 1.50 \\
\hline Netherlands & 360 & 1.27 \\
\hline Switzerland & 340 & 1.20 \\
\hline
\end{tabular}

The NASSCOM estimates the global market and the opportunity for Indian Exports to a level of US $\$ 700$ billion and India's exports form about $5 \%$ of the global market by 2005. The NASSCOM review chapter also indicates that the Internet subscribers base will grow from 5,11,376 persons in 2001 to 56,33,322 persons in 2006. The position in regard to software exports classified on area of expertise is set out in the Table below: 


\begin{tabular}{|l|r|r|r|r|r|r|}
\hline \multirow{2}{*}{ Area of expertise } & \multicolumn{2}{|c|}{$1999-00$} & \multicolumn{2}{c|}{$2000-01$} & \multicolumn{2}{|c|}{$2001-02$} \\
\cline { 2 - 6 } & Export & $\%$ on Total & Export & $\%$ on Total & Export & $\%$ on Total \\
\hline Application Software & 1223 & 64.0 & 1167 & 39.5 & & \\
\hline Online consultancy & 470 & 25.0 & 739 & 25.0 & & \\
\hline System software & 139 & 7.0 & 626 & 21.2 & & \\
\hline IT enabled & 68 & 4.0 & 260 & 9.0 & 340 & 6.65 \\
\hline Web Application & 9 & 0.5 & 121 & 4.1 & 180 & 3.53 \\
\hline Products/Package & 5 & 0.3 & 43 & 1.5 & 17 & 0.32 \\
\hline
\end{tabular}

Tamil Nadu Scenario: The Information Technology Industry has opened up tremendous opportunity for the promotion of Software exports and services in the State in recent times. A sound Agro-industrial base and infrastructure, world class connectivity, comfortable power position, world class health care, top grade educational institutions and outstanding human resources have made Tamil Nadu a highly favoured destination in Information Technology related activities.

For the Ninth Plan, the State had drawn up an ambitious plan to improve its contribution from $7 \%$ to $20 \%$ in software exports by the end of Ninth plan. The actuals indicates that the State achieved $14.7 \%$ of All India Software Exports. The hardware exports from Tamil Nadu were at the level of Rs. 482 Crores at the end of the Ninth Plan. Despite industry recession, Indian Information Technology Industry has registered a growth rate of $33 \%$ in IT exports in 2001-02. Tamil Nadu which crossed US \$ 1 billion mark in exports in $2001-2002$ registered a growth rate of $67.6 \%$. The year-wise position of software exports from Tamilnadu may be seen from the Table below:

\begin{tabular}{|c|c|c|}
\hline Year & No. of Units & $\begin{array}{l}\text { Exports in } \\
\text { Rs. crores }\end{array}$ \\
\hline $1996-97$ & 69 & 161 \\
\hline $1997-98$ & 108 & 393 \\
\hline $1998-99$ & 166 & 1246 \\
\hline $1999-00$ & 596 & 1914 \\
\hline $2000-01$ & 757 & 3116 \\
\hline $2001-02$ & 866 & 5223 \\
\hline
\end{tabular}

The geographical distribution of software export units is as follows:

\begin{tabular}{|l|r|}
\hline Place & $\begin{array}{l}\text { No. } \\
\text { Units } \\
(2000-01)\end{array}$ \\
\hline Chennai & 676 \\
\hline Coimbatore & 66 \\
\hline Madurai & 5 \\
\hline Tiruchi & 2 \\
\hline Tiruppur & 2 \\
\hline Vellore & 1 \\
\hline Dindigul & 1 \\
\hline Tirunelveli & 2 \\
\hline Erode & 1 \\
\hline Tanjore & 1 \\
\hline Total & 757 \\
\hline
\end{tabular}

As regard domestic software production, the opening up of economy has resulted in companies not reporting their achievement to their respective authorities. In view of non-regulatory regime, the exact picture on the performance of Information Technology cannot be drawn up. It is estimated that about 45,000 professionals are employed in Tamil Nadu in IT sector. Reputed organizations like the World Bank, ABN - AMRO, and EDS have established their back offices and Global Development Centres in Chennai. Bharti Enterprises, Reliance Infocom, the private telecom service providers have started operations in Tamil Nadu. M/s. Bharti is constructing the world's biggest submarine Optical Fibre Cable project-i2i connecting Chennai and Singapore. The telecommunications backbone of the State is also being strengthened by providing an Optical Fibre Cable (OFC) network to every nook and corner of the State. Tamil Nadu announced a comprehensive IT policy in 1997, the main elements of which were:

1) To encourage and accelerate the growth of hardware and software industries and associated sources in the State and to remove the bottlenecks for starting and running such units in Tamil Nadu.

2) To increase both domestic and export earnings of software and hardware sectors in the State. 
3) To upgrade and develop manpower skills required for the information technology industry by facilitating training, to accelerate the use of information technology in schools, colleges and educational institutions with a view of providing skills and knowledge to the youth to make them fit for employment in this sector.

4) To upgrade the quality of life of the citizens of the state by facilitating access to consumer application of information technology.

The policy also mentioned the existing incentives (tax concessions and subsidies) as well as the new infrastructure initiatives such as information technology parks, telecom services/information backbone and the venture capital fund for development of the information technology industry in the State. With respect to human resource development, the policy initiatives included the setting up of training institutions, computer training in schools, etc.

\section{Information Technology Infrastructure:}

- Optical Fibre Cable (OFC) - Six agencies have been permitted on a non-exclusive basis to create high bandwidth OFC networks to cover the entire State.

- Software Technology Parks of India (STPI) has been given financial assistance to set up international data links at Madurai, Tiruchi, Tirunelveli and Chennai. This is in addition to the STPI and VSNL facilities at Coimbatore. This will facilitate the spread of the information technology industry; including software and ITES and create employment opportunities throughout the State. - Information Technology Corridor - The Tiruporur Information Technology Corridor along the Old Mahabalipuram Road will be provided with world class infrastructure and Knowledge Industry Townships (KITs) aimed at Knowledge Oriented Industries.

Telecom Infrastructure: The telephone density in Tamil Nadu is one of the highest in the country second only to Kerala in the southern states as given in Table below:

Telephone Density in Southern States

(As on March 31, 2000)

\begin{tabular}{|l|c|c|c|c|}
\hline State & $\begin{array}{l}\text { Area in '000 } \\
\text { sq. km. }\end{array}$ & $\begin{array}{c}\text { No.'OOO of } \\
\text { Telephones }\end{array}$ & $\begin{array}{l}\text { No. Per sq. } \\
\text { km. }\end{array}$ & $\begin{array}{l}\text { No. Per 100 } \\
\text { Population }\end{array}$ \\
\hline $\begin{array}{l}\text { Andhra } \\
\text { Pradesh }\end{array}$ & 275 & 2333 & 8.5 & 3.1 \\
\hline Karnataka & 192 & 1957 & 10.2 & 3.8 \\
\hline Kerala & 39 & 1812 & 46.5 & 5.6 \\
\hline Tamil Nadu & 130 & 2840 & 21.8 & 4.5 \\
\hline All-India & 3287 & 28396 & 8.7 & 2.9 \\
\hline
\end{tabular}

Source: Indian Telecommunication Statistics (2000). Ministry of

Communication

Tamil Nadu has nearly 100 per cent rural connectivity in terms of Village Phone Terminals (VPT) compared to the All-India average of 67 per cent as given in Table below:

Rural Coverage - Telecom

(As on March 31, 2001)

\begin{tabular}{|l|c|c|c|}
\hline \multicolumn{1}{|c|}{ States } & No. of Villages & No. of VPTs & \% Coverage \\
\hline Andhra Pradesh & 29460 & 23383 & 79 \\
\hline Karnataka & 27066 & 27056 & 100 \\
\hline Kerala & 1530 & 1530 & 100 \\
\hline Tamil Nadu & 17991 & 17898 & 99 \\
\hline All - India & 607491 & 408922 & 67 \\
\hline
\end{tabular}

Source: www.bsnl.con.in

\section{Information Technology Parks}

- TIDEL Park, a one million square feet information technology park is now functioning in - Taramani. Reliable power supply and communication / uplink facilities are critical requirements of software companies which are provided at TIDEL Park. TIDEL-II with a floor space of two million square feet is being planned.

- Elnet City - Elnet is a joint sector company of the Electronics Corporation of Tamil Nadu (ELCOT) with the objective of constructing and maintaining the first private sector software technology park in the country. Elnet City has a built up area of 140,000 sq.ft. and is part of the Cyber Corridor in Taramani.

- SIPCOT has developed a 1000 acre information technology park in Siruseri village, $20 \mathrm{~km}$. south of Chennai, for allotment of land to information technology companies. There has been good response from large companies like TCS.

- The 1700 acre Mahindra Park a joint venture of TIDCO, ILFS and Mahindras is being developed south of Chennai near the Airport.

- Tex City - A Software Park with 90,000 sq. ft. space is located close to the Coimbatore Airport to encourage prospective software developers to locate their office space.

E-Governance initiatives in Government: The State has made considerable strides in the use of Information Technology in the day to day administration and in public - Government interface. Rural connectivity is sought 
to be provided by Rural Internet Kiosks. SARI (Sustainable Access in Rural India), a rural connectivity pilot project was taken up in Melur Block, Madurai District which has been upgraded as RASI (Rural Access to Services through Internet) to cover all districts in a phased manner starting with 10 districts - Madurai, Cuddalore, Coimbatore, Kancheepuram, Theni, Thiruvallur, Erode, Salem, Tirunelveli and Nagapattinam. The Rural Internet Kiosks will open channels of communication for the people with the Chief Minister's Office and the District Offices - enabling the people to air their grievances, obtain information on rainfall, market price information and access Agricultural Extension \& Veterinary and Health Services and also prefer applications online for Births, Deaths, Income, Community and Nativity Certificates.

Revenue Department - Under the computerization of the land records programme - Tamil Nilam - (Tamil Nadu Infosystem on Land administration and Management) all the 206 taluk offices have been fully computerized and the data digitized. The project has been undertaken in two phases - Phase I and Phase II with a cost involvement of Rs. 132.60 lakhs and Rs. 406 lakhs. With Tamil Nilam, the citizens access to the land records has become easier \& faster. The Touch Screen Kiosks at the 30 Model Taluk Offices will enable the public to view details like land, patta, guideline value, birth details etc., at one touch. The facility has been designed with a built-in revenue model at an outlay of Rs. 62 lakhs.

Transport Department - Issue of Computerized laminated license system has been established in all the RTO /Unit Offices in the State. The computerization of Transport Offices is being introduced in a phased manner with $17 \mathrm{RTO}$ / Unit Offices having become operational in Phase I. The balance $73 \mathrm{RTO} /$ Unit Offices will be covered in Phase-II.

Judiciary - A comprehensive computerization programme covering various operations in the High Court has been taken up in a phased programme.

Education - An ambitious programme to impart 'computer literacy and education' in all the Government Higher Secondary Schools was taken up and a total of 1,197 schools covered - 666 in Phase I and 531 in Phase II with an outlay of Rs. 112.33 crore and Rs. 77.40 crores respectively. Similarly, all the Government Arts and Science and Law Colleges numbering 65 have been covered for the IT Education Programme benefiting 14,000 students. The Anna University has undertaken the issue of computerized Hall Tickets for Tamil Nadu Professional Course Entrance Examination (TNPCEE) enabling efficient online services in a critical period. Students' counselling for allocation of branches in professional streams through IT enabled system has been undertaken with an outlay of Rs. 2 crores benefiting about 50,000 people resulting in counselling services being rendered much faster. Backward Classes - Computer Training to enhance the IT skills and employment prospects for BC candidates has been undertaken - the project has been implemented in 127 centres with an outlay of Rs. 5.09 crores covering 4077 students.

Housing and Urban Development - The operations of the Tamilnadu Cooperative Housing Federation office in Chennai have been fully computerized to enable speedy loan application clearances and improve the internal efficiency of the Federation. Small Industries - A system for online registration for issue of provisional SSI registration certificate through browsing centers is being launched shortly by the Small Industries Department.

Health and Family Welfare - Computer education has been introduced in all the State Government Medical and Dental colleges with a outlay of Rs. 1.70 crore and a coverage of 1400 students. The operations of Tamil Nadu Medical Services Corporation have been fully computerized with an outlay of Rs. 30 lakhs. It is a model of Eprocurement of Drugs and Medicines over Rs. 100 crores in the Health sector. Under this, an efficient and centralized procurement and distribution system has been put in place.

Commercial Taxes - 140 out of 323 assessment circles have been computerized with an outlay of Rs. 3.57 crores enabling better tax collection and faster and efficient services to tax payers.

Registration - A massive and comprehensive computerization of the department has been undertaken under project STAR (Simplified and Transparent Administration of Registration) in a phased manner to cover all the 650 offices. Phase-I covered 25 Sub Registrar offices / District Registrar offices with an outlay of Rs. 1.25 crores and in Phase-II 225 offices with an outlay of Rs. 54.34 crores. The remaining offices will be covered in Phase-III. This has enabled issue of EC certificates, document registration and guideline value information access in a pleasant and easier manner.

Electricity Department - Computerization to cover low tension billing, coal billing and inventory management has been undertaken in Tamil Nadu Electricity Board with an outlay of Rs. 1.78 crores. A pilot project of IT enabled citizen payment centre is operational in T.Nagar Zone, Chennai. The scaling up this project is on the anvil.

Municipal Administration and Water Supply - Chennai Corporation has implemented an ambitious IT Project that involves online education, provision of internet connection, multimedia projectors for Chennai Corporation Schools. Phase-I is covering 50 schools at an outlay of Rs. 115 lakhs. The total number of student beneficiaries is about 40,000. A web enabled service covering Metro water and TWAD has been implemented. A massive programme for computerization of the Urban Local Bodies with World Bank assistance is being undertaken. 
The website provides information about Rainwater Harvesting, Village Information System, Water Quality and Geology Information.

Co-operation, Food and Consumer Protection - The printing of ration cards has been computerized.

Public Department - ISDN connectivity based Video Conferencing System has been setup between the State Headquarters and District Collectorates. This will be expanded to cover the Police Headquarters and the field offices. A high speed inter-connectivity of $2 \mathrm{Mbps}$ has been provided in the Secretariat so that the nerve centre of administration does not lag behind in access to information for crucial decision making. A Dataflow and Knowledge Management for computerization of Secretariat will be introduced. SKS (Secretariat Knowledge System) will be implemented.

IT in Tamil - Government has set up the TVU - (Tamil Virtual University), a Globally First Virtual University for language learning. The website has been recently inaugurated and made available for Tamil Diaspora globally.

An OCR - (Optical Character Reader) in Tamil has been developed under the Tamil Software Development Fund of the Government. This is the first commercial OCR in Indian Language. The introduction of Tamil OCR is expected to enhance Tamil computing for capture and editing of printed text images.

A massive exercise of converting all Government websites in bilingual form (Tamil \& English) for dissemination of information to the public at large in rural areas is being undertaken by TVU \& ELCOT jointly.

Information Technology Enabled Services (ITES): The Tamil Nadu Government is exploring the possibility of setting up a special purpose vehicle to develop and promote Coimbatore, Madurai and Trichy as preferred hubs for ITES. ITES is one of the fastest growing segments of the information technology industry worldwide. Tamil Nadu is well placed to develop the ITES sector because of its better educational and overall infrastructure.

New Information Technology Policy of Tamil Nadu: During the 2002-03 Budget session, the Governor's address outlined the 15 Point Programme of the Chief Minister which indicated technological leap frogging for promotion of Information Technology and stressed on coordinated efforts between academic know-how and field level do how, launching a movement for fostering greater public understanding of the Science and promoting a new social contract between scientist and society. The Chief Minister announced the New IT Policy - 2002 on the $19^{\text {th }}$ of September, 2002 designed to establish the State as the "Destination of Choice" for IT investments. Outlining a road map to make Tamil Nadu the "Information Technology - Enabled Services and Business Process Out sourcing capital of the World" the Chief Minister highlighted the strategies envisaged in the new IT Policy towards achieving the desired the goals in IT Sector and to bring Tamil Nadu to number one position in the country.

Recognising the increased role for the private sector in Information Technology Development, e-governance initiatives would be implemented through public-private partnership with suitable revenue sharing models. The Information Technology would be used for sharpening the competitiveness of old economy industries, for connecting people in remote rural areas with urban centres and generating rural wealth and employment. The policy directives for deployment of scarce resources through an appropriate 'return on investment' strategy were needed for translating this grand vision into action points. The new policy would lay special emphasis on application services and development of Information Technology in Tier-II cities such as Coimbatore, Salem, Madurai, Trichy and Tirunelveli besides strengthening the areas focussed Information Technology installed capacities and institutions, Information Technology infrastructure and connectivity to Information Technology Parks. The Government of Tamil Nadu will launch special drives for making its cities vibrant and innovative, customer focussed and

conforming to international standards in quality of life indicators to make the State a 'Knowledge Power House' to capture $20 \%$ of Indian market in IT exports by the end of Tenth Plan. IT \& ITES would be the "guided missiles" for ushering in a new era of rapid development and prosperity in the State.

\section{Highlights of new I.T. Policy (2002)}

- Government set on developing the State as a global centre for Business Process Outsourcing (BPO) and investment destination for IT industry. Large pool of technically qualified human resource in Tamil Nadu, particularly in important tier - two towns such as Coimbatore, Madurai, Tiruchi, Tirunelveli and Salem could be utilised to ensure development of BPO potential.

- To upgrade the quality of life through e-governance.

- To bridge the digital divide by accelerating internet penetration in rural areas, setting up of Kiosks and Online libraries and a bilingual internet portal with links to State Government departments and services; to accord a prominent role to Tamil in Information Technology.

- To encourage $\mathrm{R} \& \mathrm{D}$.

- To promote e-governance and IT applications in Government and introduce Electronic Delivery of Services (EDS).

- New Fiscal Incentives to IT entrepreneurs besides continuing the existing concessions. 
- IT companies to be allowed self-certification on issues pertaining to various Labour Acts and Shops \& Establishments Act.

Business Process Outsourcing: Now the fastest growing industry, electonic back-office operations have emerged as India's new sunshine sector. Business Process Outsourcing is now the fastest growing industry in the country - it expanded at an explosive 70 per cent last year. This is despite a dotcom implosion and a sluggish international economy that slowed up even the country's hot-shot information technology sector. India is now the electronic housekeeper to the world, taking care of a host of routine activities for multinational giants. Business Process Outsourcers or simply call centres here handle these companies' worldwide credit-card inquiries, churn out invoices, prepare pay rolls, reconcile daily accounts, write medical transcriptions, process application, write cheques and even do billings and collections. More than a quarter of the Fortune 500 companies such as GE, American Express, British Airways, HSBC, Citibank and AT \& T, are shifting their back-office operations to India.

The reason is simple: India churns out two million English-speaking graduates every year whose wages are 80 per cent less than their western counterparts, saving foreign companies enormous sums of money on such services. In India, a call centre associate is available for Rs. 45 an hour while his American counterpart charges Rs. 550. The rule of thumb is an annual savings of $\$ 30,000$ (Rs. 15 lakh) for every call centre employee. There has also been a fortuitous set of global trends that have seen multinationals mercilessly slash costs to beat the recession and concentrate on their socalled core competencies. This has meant that mundane back-office tasks such as accounts and administration if done cheaply over fibre-optic networks or satellite telephony could be outsourced to offshore locations. India has been a favorite destination for other reasons too. In just two years, it effected a 110 per cent drop in the international private lease line rates with an equally dramatic fall in longdistance telephonic charges.

- 2 million is the total number of jobs that outsourcing centres in India will provide in six years. Currently they employ $1,10,000$ people.

- Rs. 1,15,200 crores or $\$ 24$ billion is the revenue expected from this sector in 2008 which will be 3 per cent of India's GDP. Today it is $\$ 1.47$ billion.

- 71 per cent was the rate of growth last year in this sector making it the fastest growing industry.

. 336 is the number of centres in India that have come up in the past five years. In the past year alone, 50 major new ventures were set up.

- India is ahead of the pack of providing IT enabled services by a huge margin. Its closest rivals are the Philippines and Ireland. (Source: India Today, Nov.18, 2002)

The State's Information Technology Policy 2002 is summarised below.

Vision

To put the smile of prosperity on the face of every citizen of Tamil Nadu by leveraging Information Technology to create value and wealth for a knowledge-based State.

Objectives

- To establish Tamil Nadu as the Destination of Choice for IT investments.

- To upgrade the quality of life for the citizens through e-Governance and IT applications in Government.

- To empower people in the rural areas so as to bridge the Digital Divide.

- To develop Research and Development initiatives.

- To promote use of Tamil in Information Technology.

Destination of Choice

The Government of Tamil Nadu will launch special drives for making its cities vibrant and innovative, customer-focussed and conforming to international standards in quality of life indicators to make the entire State a knowledge powerhouse to capture $20 \%$ of Indian market by the end of the Tenth Plan period.

Concessions available to the IT industries

Existing concession available for IT industries will be continued. In addition the new incentives announced are as given below:

Fiscal Incentives etc.

- Relaxation of FSI (Floor Space Index) to the extent of 100\%

- 50\% upfront exemption of the Stamp Duty and the Registration Fee.

- Special concessions will be given to the IT Companies giving employment opportunities to the physically challenged persons.

- Government of Tamil Nadu will collaborate with leading institutions for the development and promotion of specific software for the use of physically challenged persons.

Administrative Incentives

- Further exemption from the provision of Chapter III of the Tamil Nadu Shops and Establishment Act covering sections 12 to 16 . 
- IT Companies will be permitted to self certify that they are maintaining the registers and forms as contemplated under different acts and rules.

Physical Incentives

- The requests of the IT Companies for maintaining the OSR (open space reservation) will be considered favourably.

- Tamil Nadu will be positioned to attract investments in areas of Disaster Recovery and Business Process Continuity.

- Motor Vehicles Act has been amended to enable the IT Companies to make use of hired privately owned omnibuses.

- Annual awards for excellence (which will include export performance) will be instituted by the Government for IT Industries.

Infrastructural Incentives

- Separate task forces on Cyber Security, Prevention of Cyber Crimes and IT infrastructure will be established.

Promotional Initiatives

Social Initiatives

- Corporate health services, golf courses, international schools and such other special needs will be made available for business houses by encouraging private initiatives.

Infrastructural Initiatives

- Knowledge Industry Townships (KITs) will be created in the IT highway in Chennai through a Public Private Partnership program.

- A Special Purpose Vehicle (SPV) will be created to own and take forward the initiatives to position Coimbatore, Madurai, Trichy, Tirunelvelli and Salem as the best Tier-II cities for IT investments.

Physical Initiatives

- Enabling mechanism will be created so that existing infrastructure in industrial estates like Perungudi/Maraimalai Nagar/Ambattur could be put into use in a cost effective manner by IT Companies.

Human Resources Development Initiatives

- Basic training in computers will be introduced in all schools from the high school level.

E-Governance and I.T. Applications in Government

- Plans to introduce Electronic Delivery of Services (EDS)

- All Elected Representatives will be trained on the use of Computers and E-Mail.

- Suitable innovative schemes to upgrade the levels of IT usage in Government Departments.

- Touch screen kiosks with suitable bilingual software and internet facilities will be deployed through out the State.

- Government will come out with guidelines for e-signature and Electronic records as per Section 6 of the IT Act 2000 .

- Government of Tamil Nadu will set a specific annual target for egovernance activities of each department.

- Government will establish a Portal for exchange of information and views on the directions of the Government's IT strategy.

Bridge the Digital Divide

- Tamil will be given a prominent role in IT.

- The process of PC and Internet penetration in the rural area will be accelerated.

- A bilingual Internet portal will be set up with links to State Government departments and services to provide single window access "Any Time Any Where".

- Government will encourage setting up of Internet Kiosk and Online Libraries in existing Infrastructure like

Public Libraries/Public Government Offices throughout the State.

Research and Development Initiatives

- Tamil Nadu Government will leverage the State's Unique Selling proposition (USP) of an 'intellectual powerhouse' to convince IT MNCs to set up research centres in Chennai.

- Investments in Very Large Scale Integrated chip (VLSI) design services/ Application Specific Integrated Circuits (ASIC) design services and Embedded System design will be promoted for enhancing the employment of highly qualified professionals.

- Enabling initiatives will be undertaken to seed R\&D activities.

Tamil in Information Technology

- The Government will facilitate Research in Tamil Computing.

- The Tamil Software Development Fund (TSDF) will be further strengthened for devising IT solutions in Tamil.

- All websites will be converted into Bilingual.

Summary 
Tamil Nadu will consolidate its leadership position and firmly establish its pre-eminent position in IT. The strength of Tamil Nadu especially in Tier-II cities will be marketed globally to attract and retain foreign investments. Additionally Tamil Nadu based IT Companies will be encouraged to globalise their operations. The large base of engineering institutions in the State is a significant asset. They will be encouraged to interact with industry, centres of excellence so as to have the best match of Industry-Academia. The Government emphasis will be on governance with transparency. This policy is aimed at removing illiteracy and promoting technocracy, creating opportunities specially targeting rural areas. Tamil will be given a prominent place not only in the IT world but also in the commercial world. Sufficient mechanism will be created to implement cyber laws. Software piracy, IPR issues and violation of cyber laws will be curbed. Enabling mechanisms and institutions will be created for this purpose. Technical capabilities of the State Police will be enhanced to handle cyber crime. In short, this policy will make Tamil Nadu as the "Destination of Choice" for IT investments globally. The State will transform from inline to online thereby becoming the Knowledge-

Capital of India.

\section{Tenth Five Year Plan (2002-07) : Programs \& Outlay}

The expenditure on Information Technology activities is debitable to the heads of account of the concerned departments performing them. Promotional activities and expenditure of a general nature were reflected in the budget of Industries Department in the Ninth Five Year Plan period. A major effort to promote Information Technology sector is proposed in the Tenth Plan period (2002-07). The Government will continue to be a facilitator and act as a catalyst for the accelerated growth of Information Technology. The Electronics Corporation of Tamil Nadu, (ELCOT) under the aegis of the Department of Information Technology would undertake promotional, Research \& Development activities, facilitating and coordinating with various institutions and departments, creation of general infrastructure for Information Technology development, etc. The Department of Information Technology would accelerate e-governance in Government during the Tenth Plan.

Towards this end the following activities are proposed to be taken up by Information Technology Department/ Electronics Corporation of Tamil Nadu Ltd. (ELCOT) during the Tenth Plan period.

1) Research and Development $(R \& D)$

New emerging technologies need support through fundamental Research and Development activity. Nano Technology is one such new promising technology for potential usage in the effective delivery of health, energy and computing. ELCOT had sponsored an international conference on Nano Computing at Thanjavur in December 2001. ELCOT would organize similar conferences with the collaboration of leading institutions in the State during the Tenth Five Year Plan period. The Government of Tamilnadu, the Government of India and Massachusetts Institute of Technology, USA would jointly establish a regional laboratory in Chennai to take up advanced $\mathrm{R} \& \mathrm{D}$ areas in communication computing.

ELCOT and Indian Institute of Technology (IIT) would set up an International Research and Development Park in Information Technology enabling Tamil Nadu to achieve World Standard in Information Technology. ELCOT would also make investments in Very Large Scale Integrated chip (VLSI) design services/Application Specific Integrated Circuits (ASIC) design services and Embedded System design for enhancing the employment of highly qualified professionals.

The requirement of funds for R \& D activities during the Tenth Five Year Plan is indicated to be Rs. 15 crores.

2) Information Technology in Tamil

The Government has set up the Tamil Virtual University (TVU), globally the first Virtual University for language learning. The website has been recently inaugurated and made available for Tamil Diaspora globally. An Optical Character Reader in Tamil has been developed under the Tamil Software Development Fund of the Government. A massive exercise of converting all Government websites in bilingual form (Tamil \& English) for dissemination of Information to the public at large in rural areas is being undertaken by TYU \& ELCOT jointly. Tamil Virtual University (TVU) and ELCOT will work together for devising IT Solutions in Tamil and facilitating research in Tamil Computing and for the development and use of Tamil software and Digital Library by Tamil Virtual University for universal usage. The requirement for the above purpose is indicated as Rs.5 crores during the Tenth Five Year Plan.

3) Promotion of Tamil Nadu as Destination of Choice

The Government of Tamil Nadu is committed to make Tamil Nadu a knowledge powerhouse by the end of the Tenth Plan period. ELCOT would participate in International /National events like exhibitions and conferences to attract prospective investors to Tamil Nadu. For this purpose, ELCOT will launch special purpose vehicles to study and provide world class infrastructure for attracting Information Technology investments in the cities of Coimbatore, Tiruchirapalli, Madurai and Tirunelveli. For this purpose a sum of Rs.7.50 crores is proposed during the Tenth Five Year Plan period making Tamil Nadu as Destination of Choice in Information Technology sectors. 
4) Creation of Information Technology Infrastructure including Knowledge Industry Townships (KITs)

Thiruporur Information Technology corridor along the old Mahabalipuram road needs to be provided with world class infrastructure and Knowledge Industry Townships aimed at addressing the basis concerns of knowledge oriented industries. KITS will be set up in public private partnership in association with the Confederation of Indian Industry. SED investments and study through consultants are needed for carrying forward these initiatives. For the above purpose a sum of Rs. 10 crores is proposed during the Tenth Five Year Plan period.

5) E-Governance activities in Government

The Government with active co-operation of Electronic Corporation of Tamil Nadu Ltd. (ELCOT) will further strengthen e-governance activities in Government to achieve internal efficiency. For this purpose a sum of Rs.12.50 crores is proposed during the Tenth Five Year Plan period. For the above activities, the financial support envisaged from the Government is of the order of Rs.50 crores as indicated below.

\begin{tabular}{|l|r|}
\hline 1) Research and Development & Rs. in crores \\
\hline 2) Information Technology in Tamil & 5.00 \\
\hline 3) Promotion of Tamil Nadu as Destination of Choice & 7.50 \\
\hline 4) Creation of Information Technology Infrastructure & 10.00 \\
\hline 5) E-Governance in Government & 12.50 \\
\hline Total & 50.00 \\
\hline
\end{tabular}

Necessary provisions will be made in the Annual Plans and in the Mid- Term Appraisal and approval of the Union Planning Commission for consequential changes in sectoral outlays obtained at the appropriate stage. (A provision of Rs. 10 crores has been made in the Budget Estimate for 2002-03 under Demand 30 IT Department 2852 Industries 07 Telecom. \& Electronic Industries)

The success of Indian firms and professionals in the information technology (IT) arena during the last decade has been spectacular. Entrepreneurs, bureaucrats, and politicians are now advancing views about how India can ride the IT bandwagon and leapfrog into a knowledge-based economy. Isolated instances of villagers sending and receiving email messages or surfing the Internet are being promoted as examples of how India can achieve this transformation, while vanquishing socio-economic challenges such as illiteracy, poverty, and the digital divide along the way. Likewise, even while a miniscule fraction of the population has access to computers and the Internet, e-governance is being projected as the way of the future. There is no dearth of fascinating stories about IT-enabled changes, yet there is little discussion about whether such changes are effective and sustainable in the absence of the basic infrastructure that is accessible to the citizens of more advanced economies.

The statistics speak loudly and clearly. Seventy nine percent of India's population lives in villages without the basic amenities and infrastructure that can sustain a knowledge economy. While over $60 \%$ of the population is considered to be literate, note that the relevant definition of literacy that supports this statistic is being able to read and write simple words in any language, acquired with or without formal schooling. This criterion is so basic, that it is almost irrelevant in the context of a knowledge economy. Yet, the central and state governments in India are investing millions of dollars in promoting IT-based initiatives and the IT industry as vehicles of social and economic transformation. Are we putting the cart before the horse here? Even if substantial IT investments are justifiable, how must the IT revolution proceed so that the nation is benefited in a wholesome and balanced way?

This commentary aims to open a debate regarding the impact of IT on a developing country like India. We argue that India should aggressively pursue traditional manufacturing and agriculture-based industries to build a robust industrial economy that can be made more efficient and productive with IT. In turn, policy makers should moderate their obsession with IT and IT-related ventures as a panacea to solve socio-economic problems. ITrelated projects must definitely be pursued, but the private sector must bear the risks and capture the returns related to these projects, much like it does in any other sector of the economy. We argue that government actions cannot be disproportionately skewed towards a single industry when its benefits to the common man are still not well understood, and when the role of IT within the broader framework of national development has not yet been adequately articulated. Not everyone will agree with this viewpoint - but then, neither does this commentary pursue such a consensus.

Such a debate is even more critical with the recent worldwide bursting of the IT bubble. Booms and th

busts have long existed in all kinds of markets - during the 17 century tulip bubble, for example, the irrational exuberance of tulip buyers drove the value of each tulip to several thousand dollars. In 1637, a single Semper Augustus tulip sold at a price that was three times the value of the most expensive estate in Amsterdam! However, such booms and busts apart, in a reflection of the well-known IT "productivity paradox," even serious researchers, CIOs, and economists in the corporate world (including Stephen Roach, the respected Chief 
Economist at Morgan Stanley) have struggled to convincingly demonstrate the benefits of IT to the corporate sector.

Equally important, proponents of "new growth theory" including noted Stanford economist Paul Romer have convincingly argued that ideas and knowledge, rather than scarce physical resources, increasingly fuel economic growth. Ideas and knowledge are, in turn, endogenously generated within an economy, as a function of the prevalent levels of education, the skills of the workforce, and proper market incentives. The message in the Indian context is straightforward - progress into a knowledge economy will not come without substantial, widespread development of India's human potential. Against this backdrop, before embarking on a series of irreversible commitments related to IT, it behooves Indian policy planners and politicians to ponder the following issues.

The economic value of IT depends greatly on the levels of economic progress a nation has already achieved. IT has the potential to make existing processes more effective and efficient, but cannot substitute for the lack of a basic infrastructure. What is good for a developed country like the U.S. is not necessarily optimal for a developing country like India when those basic elements of infrastructure that support a successful economy such as educational opportunities, healthcare, electricity, drinking water, and capital are still in short supply.

The impact of IT is best understood when the fundamental differences between the innovations and ventures of industrial and knowledge-based economies are recognized. Industrial growth yields from investments in largescale infrastructure (e.g., railroads, roadways, power grids, and dams). These investments, in turn, support the growth of physical-asset intensive industries (e.g., the steel, chemical, and transportation industries) that create and move physical entities (e.g., people, water, and goods). The ventures of an industrial economy typically employ large numbers of workers with minimal training, education, and skills. These ventures have the potential to uplift large sections of the population.

In contrast, innovation in the knowledge economy usually engenders highly specialized knowledgeintensive products, and the large-scale capture, movement, and usage of information using sophisticated network infrastructure (e.g., computers, cable, fiber, and routers). Beyond the physical labor required for initial construction, building and maintaining this kind of infrastructure requires specialized skills and training. It follows that the IT sector, in itself, would offer relatively modest employment opportunities for India's teeming population, even if India was to become the world's software factory.

Further, despite all the hype of moving into a "new" economy, the fact is that economic development is cumulative. The past matters because economic development builds on preceding accomplishments. The industrial economy made agriculture more efficient and productive. The productivity of agricultural labor skyrocketed with the use of industrial and biological innovations including tractors, fertilizers, irrigation systems, pesticides, and genetically engineered seeds. It is not surprising, therefore, that the greatest source of real productivity, growth, and efficiency attributed to the information economy derives in the long run not from the information economy itself, but from its effects on the industrial economy. For example, the intelligent use of IT can help product distribution channels and manufacturing plants to work more efficiently.

Historically, sustained industrial innovation in developed economies has created great wealth and improved living standards across societal divides. This progress has set them up in an ideal position to exploit and create knowledge as they transform into knowledge-based economies. One aspect of this transition is that, increasingly, labor-intensive manufacturing and low-end service jobs are being outsourced to countries with lower labor costs. China has captured much of the lucrative manufacturing market, ensuring millions of jobs for its citizens. India would benefit much from aggressively pursuing such manufacturing facilities that have potential to serve both the export and domestic markets, particularly in view of its high levels of unemployment.

The "leapfrogging" argument, whereby India skips massive industrialization and moves straight into the information economy, is suspect. Proponents of the leapfrogging argument frequently advance the example where Indian villages without any electronic communications directly adopt a cellular phone, rather than work their way up through physically connected communication systems. The problem with this example is that, while it provides for some excellent symbolism, the underlying argument is not scalable to a national economy. Consider, for instance, the industrial transportation system. The rules of physics do not allow IT to substitute the physical movement of goods from one location to another by a "virtual" movement! A lightning-fast information network will not in itself help achieve the faster and cheaper transport of goods — better roadways and railways will.

\section{IT, job growth, and government investment:}

From a social planner's perspective, it is important that wealth not only be created at a societal level, but that different sections of society benefit in some measure from such wealth. The development of IT in India has, by and large, focused on developing and delivering IT services to support the more advanced economies of the world (e.g., U.S., Japan, England, Germany). Even if the most optimistic projections of the IT-related job creation (including jobs associated with IT outsourcing, call centers, and design centers) in the next decade 
come true, this industry will employ at the most a couple of million people. In a nation with over 1 billion people, this level of employment can make but a minor dent in the employment statistics.

Further, in the zeal to establish call centers in India, many have ignored the fact that numerous Englishtrained and highly educated members of the workforce are being relegated to tasks that are generally manned by workers with much more modest levels of education in the advanced economies. Moreover, is this model economically sustainable in the long run? Call centers, by and large, are commodities. Due to intense competition, prices for some of these services have fallen so dramatically that many call centers are already struggling to survive. Also, it is very likely that other developing nations with even cheaper labor and growing English-speaking populations will compete with India in this area in the near future. Call centers, unlike manufacturing plants, can be shifted easily from one country to another - it is difficult to achieve "lock-in" in this arena.

Further, the IT industry holds limited potential for wealth to trickle down to the poorer sections of society. Unlike a steel plant or a power plant, IT engenders few opportunities for the unqualified. Any transfer of wealth from the IT sector (e.g., by taxing the IT sector to fund social spending) would be achieved through the heavy hand of government, which represents, at best, a dubious economic proposition. In fact, one consequence of the IT revolution in India, at least in the short term, will likely be the establishment of a digital divide, where the rich and educated are empowered and enriched by IT, and the poor are oblivious to its impact.

Before embracing IT as the engine of growth, Indian social planners need to take a hard look at those investments that are likely to yield the greatest returns at a societal level. Let us consider, for example, one sector that is far removed from high-tech world - the jute industry. How many of us have seriously evaluated the fact that the jute industry, though declining, sustains over 5 million Indian households? In late 1980s, while working for an industrial development bank, one of us was puzzled about the government's blanket ban on the use of plastic material (e.g., HDPE) to package cement, fertilizers, sugar, food grains and other commodities only jute was to be used. From a purely economic perspective, considering that jute bags were more prone to spillage and rat-induced destruction, this regulation appeared to have no rational basis (jute packaging has much improved since then). However, in retrospect, given the millions of people employed in that industry, and the economic and political upheaval that would incur if that industry rapidly declined, this policy probably had some important redeeming features.

What does IT have to do with the jute industry? At first sight, very little; but on deeper introspection, plenty. Rather than harping on the IT industry itself, imagine using the power of IT to expand the domestic and export market base for jute products, to position jute as a biodegradable material that is safe and cheap relative to plastics, and to improve the efficiency of local jute markets so that jute growers can get better prices. Now imagine how the benefits that would potentially flow from such initiatives could positively affect millions of Indian households. This does not call for Internet access to every jute cultivator or processor, or for computers in each village. A public or private agency with the right incentives, and with access to both domestic and international marketplaces can orchestrate these initiatives. Further, governmental initiatives for R\&D related to strengthening jute products and finding other uses of jute would deliver significantly more social benefits than email access for jute farmers. In the rush toward IT, it is easily forgotten that the greatest returns to government investment at the societal level may be achieved elsewhere.

We need to be particularly careful not to give short shrift to the manufacturing sector. Consider China, our northern neighbor. China is not currently known for its strengths in IT, although it has been moving toward establishing its presence in this area. But, what China has accomplished building its core industrial base is striking. The foreign direct investment in China was of the order of $\$ 40$ billion during the year 2000 despite all the noise about alleged labor and human rights abuses. Total Chinese exports worldwide exceeded $\$ 200$ billion in the year 2000. The U.S. alone annually imports over $\$ 100$ billion worth of goods and services from China. In fact, the value of "footwear" exported annually by China to the U.S. (approximately $\$ 9.2$ billion) itself compares with or even exceeds the total value of India's annual IT exports.

Why are these numbers relevant? Exporting footwear creates millions of jobs for citizens who lack education and sophisticated skills. According to some reports, a total of 34 million jobs have been created in China on account of exports, with exports to the U.S. alone directly accounting for the creation of over 20 million jobs during the last decade. These jobs have had a significant and widespread impact on the Chinese economy, increasing the standard of living for a substantial fraction of the Chinese population. There is much we need to learn from China about how the manufacturing sector can contribute to robust and equitable economic growth. Taiwan, Malaysia, and South Korea are other countries that have flourished using a similar approach.

In contrast with the manufacturing sector, IT-based industry generally involves knowledge intensive work (with the exception of mundane data-entry jobs). The direct benefits to IT (e.g., employment in IT firms) are likely to flow to those who already have the benefits of education. The trickle-down effects of the production of information products (e.g., cleaning and maintenance staff for IT firms, restaurants, hotels) are likely to be 
modest or none in areas other than large cities. The benefits of IT implementation across other industrial sectors (e.g., employing IT toward making transportation infrastructure more efficient, and toward improving the performance of supply chains and distribution systems) are likely to be substantial, but the industrial policy does not point in this direction at the moment.

The current emphasis on IT would be less objectionable if it did not contrast sharply with the treatment meted out to other core industrial sectors. Consider the case of the Vijayanagar steel plant. This plant had the potential to transform the poverty-stricken Bellary district and surrounding areas in the state of Karnataka. The feasibility study for the plant was completed in 1967, and its foundation was laid in 1972. Finally, in 1995, more than a quarter century after taking the first steps, the government divested its interests in the (yet incomplete) project. A scaled-down and much modified version of the project is now up and running under the auspices of the private sector. Meanwhile, the global and domestic market for steel has evolved to an extent that the economic assumptions that anchored the initial feasibility assessments are worthless.

The actions of the government in the recent past have tilted in favor of the IT sector. For instance, taxes levied on software in the state of Karnataka were removed hastily within a week in response to pressure from powerful IT companies. Yet, the same government takes a long time to approve new manufacturing projects. Many workplace inspection procedures have been suspended for IT companies, whereas traditional firms are subjected to myriad regulations, many of which have not been seriously reevaluated for relevance and effectiveness in decades. The government needs a more balanced policy - one that ensures that the core industrial sector is not ignored in the rush toward IT.

It is almost fashionable now to say that India's population constitutes one of her greatest assets. That viewpoint, in our opinion, is misleading. People are assets only when they can meaningfully participate in the cycle of value creation and consumption - either by exercising buying power, or creating products and services of value to others, or by creating and harnessing knowledge. By these standards - and at the risk of sounding draconian - a good fraction of India's population is a liability rather than an asset. The government can help transform this situation by building two pillars that have supported the growth of every successful economy, i.e., a reliable infrastructure core, and widespread access to education and training. We have touched on the interface between IT and infrastructure earlier - let us now discuss the IT-education interface. Distance learning and elearning are already being touted in some quarters as solutions to India's education challenges. The proffered argument is that IT can enable the cheap and widespread delivery of education (although there is no published report on the costs of creating such an infrastructure). This reasoning ignores the real problem facing the Indian educational system - i.e., how can the children of the poor and the uneducated be provided with the incentives to come to school, stay in school, and progress to higher institutions of learning? The answer to this challenge lies in understanding physiology and economics, rather than in implementing technology. For all the drawbacks and inefficiencies encountered in its implementation, the mid-day meal program in the state of Tamil Nadu that was launched by the late chief minister M.G. Ramachandran, and that has now been adopted by some other states, addressed this challenge head on. The program was designed in recognition of a simple, but fundamental fact - the brain cannot feed when the stomach itself is unfed. It provided parents with the incentive to send their children to schools, rather than to toil in the fields. For the children to whom the benefits to education seemed like a distant, hazy mirage, it provided an immediate, meaningful reason to stay in school.

Apart from the initial excitement and novelty value that it will doubtless generate, there is little reason to believe that an IT-based learning environment will advance the cause of Indian education in any substantial way. Problems that are enmeshed in the social and economic fabric of our society need to be primarily addressed with solutions that are of a social and economic nature. Throwing technology at these problems will not make them go away. There are also economic reasons why distance learning and e-learning have a high probability of failure. Creating the infrastructure and content to support effective e-learning will be very expensive. Many startups and universities in the U.S. are still struggling to effectively deliver content and achieve learning objectives in the virtual setting. This problem will be compounded in the Indian environment due to diverse languages and the lack of underlying infrastructure. Further, the ability to surf the Internet alone does not imply a readiness to learn using the virtual medium--the new medium in itself does little to address fundamental issues related to the lack of incentives and motivation. A rush into e-learning in this situation will only lead to squandered resources.

Presenting technology as the solution to India's educational challenges is troublesome in two ways. First, it diverts our attention from issues that should really be on the front-burner. Once our attention and resources are diverted, building back the momentum in the correct direction is a monumental task. Second, by building castles in the air that will soon be blown away by the winds of reality, it does a serious disservice to the more limited, but yet substantial and real benefits of technology.

A knowledge economy is characterized by a culture of innovation. Such a culture has some key characteristics - incentives for innovation, and intellectual property protection. A culture that truly enhances innovation supports the view that to try hard and fail is perfectly fine. Yet, the educated Indian psyche has historically been 
averse to blessing the risky venture - in fact, education has been viewed as a way to avoid risky options, rather than as an enabler of intelligent risk-taking and entrepreneurship. This is a cultural mindset that hinders innovation, because meaningful innovation is almost never without significant risk. This attitude transcends into the corporate arena. It is mind-boggling to think about how static the Indian automobile industry was for almost 3 decades before the winds of competition brought about rapid change. Competition breeds innovation-when competition is absent or minimal, there is little incentive for corporations to innovate. Not surprisingly, even as markets have become increasingly competitive, R\&D spending by U.S. firms has increased sharply, at an annual rate of over $6 \%$ from $1995-2000$.

While one side of the cultural coin pertains to the incentives for innovation, the flip side pertains to its protection. Ideas, unlike property, cannot be protected by building a fence around them or by hiring guards to watch over them. The protection of intellectual property is not a purely economic issue - it has important cultural aspects as well. The economic angle can be addressed by defining newer and stronger patent laws and punitive procedures. However, the cultural issues will decide whether such protection can be enforced meaningfully. Addressing the cultural angle is a challenge - it requires that even without the threat of punishment, we learn to draw a clear, disciplined boundary in everyday life between what is ours to take and keep, and what is not.

Making the cultural shift requires that we stop treating intellectual property rights in a casual manner. For example, a frequent argument heard in support of piracy goes along these lines - "If we could afford it, we would pay for it. We are using a pirated version because we cannot pay for it." But then, how does an inability to pay for something ever translate into a justification to obtain it for free? One would be highly challenged to apply this logic to hotel stays, vacations, sea cruises, or even a television set. Piracy does exist to some degree in every economy, but rampant piracy dilutes the incentive to innovate. In the context of intellectual property, economic measures and cultural shifts should proceed hand-in-hand before the spirit of entrepreneurship in India can take full flight.

A society that is deeply divided by social and economic fissures must think carefully about how it achieves economic and technological advance. The path, in some ways, is more important than the outcome itself. Modern day Russia provides a striking example of the results of chaotic advance. The Russian economy is now in sharp decline and is expected to contract for several more years, with no light visible at the end of the dark tunnel into which it has ventured. In the Indian context, particular attention needs to be paid to when, where, and in what form IT and technological advances and are encouraged. There are, indeed, many low-hanging fruit that can be harvested. A recent New York Times article described, for example, how a fisherman working off the coasts of Kerala used a cell phone on the seas to obtain and compare information about spot market prices for fish at Cochin and Quilon (85 miles apart). This fisherman netted an additional \$1000 in annual income merely deciding to deliver his catch to the more remunerative market each time his boat came in. This striking example of how simple information flows can enhance market efficiency is being repeated in many ways across markets and regions within India. However, the stakes are quite different when it comes to the formulation of national economic policy.

The formulation of national policy requires the implementation of important tradeoffs between the benefits to industrial sectors, regions, and classes of people. The quest for superior technology must be moderated by an understanding of its implications at the social level — what might be good for a private corporation or an entrepreneur may not always be good for society, and vice-versa. For example, a municipal corporation that purchases automated road-laying or cleaning equipment may find that it either does not use the equipment at all, or that it uses the equipment and allows numerous laborers on its payroll to idle, or faces significant resistance from labor unions. Technology adoption and labor retrenchment are inextricably linked in this case, and is shortsighted to advance doggedly on one front while turning a blind eye to the other.

Successful technology adoption will move in measured steps, at a pace and in a direction that are in harmony with changes in the socio-economic fabric. The role of the government in ensuring such harmony cannot be underestimated. This is especially true in a country like India where the government remains responsible for a significant fraction of the economic output, and where it is actively involved in shaping rules and regulations as India integrates into the global economy. From the triumph of the capitalist systems across the globe, there is now ample empirical support for the view that governments must ultimately govern with a light touch. At the same time, several economies that have attempted rapid, unstructured transitions into the capitalist mode have declined. There is a strong argument to be made that the Indian government must not simply get out of the way in the spirit of laissez-faire, but must instead play a key

The growth of the IT sector in India symbolizes the potential of Indian industry to perform at world-class standards. Led by some visionaries and supported by thousands of employees and entrepreneurs, the IT sector embodies much of what can go right when the spirit of human enterprise is given free rein. IT can change how the society communicates, collaborates, lives, works, and plays. However, IT offers little value to the large fraction of the population that is more concerned with day-to-day survival. It is not surprising, therefore, that 
while India is considered a software superpower, in terms of Internet penetration India is grouped along with Latvia, Thailand and Indonesia as a low penetration country.

The success of IT at the corporate level in India cannot be translated into a panacea that will solve India's myriad economic challenges. Just like copious rainfall can lead to dramatic floods that cause widespread destruction, an obsession with IT and the knowledge economy is not useful in the Indian context. To be truly beneficial, the rain of IT must fall at the right place, in the right quantity, at the right time, and for right purpose. Economic policies of a developing country cannot be based on "herd" behavior, and on what is hot in the international market for that year or decade. Neither does the aggressive pursuit of IT represent the sole, or even an obvious, pathway to a first class economy despite the glowing success of high-profile private companies in the IT realm. Noted economist Paul Krugman, in arguing against the belief that someone who has made a personal fortune will know how to make an entire nation more prosperous, probably phrased it best. "A country," he wrote in an article in the Harvard Business Review, " is not a company!"

\section{References:-}

[1]. Arora, Ashish, V. S. Arunachalam, Jai Asundi and Ronald Fernandes (2001a), The Indian Software Service Industry, Research Policy, 30, 1267-1287.

[2]. Arora, Ashish and Suma Athreye (2002), The Software Industry and India's Economic Development, Information Economics and Policy, 14, 253-273.

[3]. Arora, Ashish, Alfonso Gambardella and Salvatore Torrisi (2001b), In the footsteps of the Silicon Valley? Indian and Irish Software in the International Division of Labour, chapter presented at the conference, 'Silicon Valley and its Imitators', Stanford Institute for Economic Policy Research, July 2000.

[4]. Bajpai, Nirupam and Anupama Dokeniya (1999), Information Technology-Led Growth Policies: A Case Study of Tamil Nadu, Development Discussion Chapter No. 729, October, Harvard Institute for International Development.

[5]. Banerjee, Abhijit V. and Esther Duflo (2000), Reputation Effects and the Limits of Contracting: A Study of the Indian Software Industry, Quarterly Journal of Economics, 115,3, 989-1017. 